\title{
Egyptian Events in the Hungarian Press 1879-1882, The Movement of Urabi Pasha
}

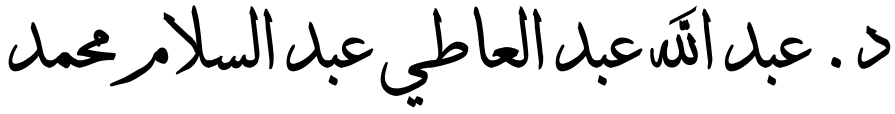


The Austro-Hungarian Monarchy, with Hungary as a founding component, did not have any direct interests in the Mediterranean and in North Africa. AustriaHungary had interests in the Balkans and in the European part of the Ottoman Empire (Bosnia-Herzegovina). Thus, indirectly it had interests in what was happening in the North African provinces of the Ottoman Empire. This is what explains the fact that the Hungarian political elite and the Hungarian public were interested in Egyptian events, especially in the movement of Urabi Pasha,1 Leader of Fellahin. 2

In the last decades of the 19th century, the European powers struggled to gain as much influence in the North African countries as they could. France had held Algeria since 1830 and Italy competed for control of Tunisia. To avoid war the Italians withdrew and Tunisia became a French Protectorate in 1882. At that point the Italians, fearing that they would lose their influence in the Mediterranean, shifted towards Germany and Austria-Hungary, and on May 20, 1882 signed a treaty with them. The first European alliance, the Triple Alliance, was formed.

France would have liked to increase its influence in Egypt, too, but the British strongly resisted it. After Paris gained control of Tunisia (partly with British support), it allowed London to increase its influence in Egypt.

The Hungarian press reported about these events in detail and provided accurate information and worthy analyses. In our essay, we primarily focus on the articles of the Vasárnapi Ujjág (Sunday Newspaper). The illustrated weekly was very popular among the urban intellectuals and the developing and growing bourgeoisie. These layers had a considerable influence on the formulation of public opinion. The paper was well-informed, and it was close to government circles. From the end of the 1870s there was an article in almost every edition about the North African countries, primarily Egypt.

For this article we also used two daily papers: Pesti Napló3 (Pest Chronicles or Pest Diary) and Pesti Hírlap4 (The News of Pest or Pest Journal). Ismail Khedive's5 reforms and the wider deposition from the leadership of Egypt in 1879 aroused a great deal of interest.

If the news is true, the pasha will disappear from political life. In his person such a ruler leaves office to whom history will be more grateful than his contemporaries. The investments he made will only have their results in the long run. He will be viewed as a man who won over the pharaohs' country for culture and who was the founder of culture. 
The framework has been preserved, the khedive's removal was carried out with the sultan's direct intervention, 6 but without changing the essentials: right now foreign powers dictate in the pharaohs' country. 7

Vasárnapi Újság also wrote about Ismail Khedive in a positive light. It published a long article about him which briefly outlined his biography and the history of the country from Muhammad Ali:8

He organized the institutions and the administration of the country on a European model. His most lasting achievement is the Suez Canal. Trade and industry flourished thanks to the high price of cotton. The reforms, however, cost a lot of money, and the khedive got into debt. In this respect, it is the Europeans who should be blamed, it is them who profited from the khedive's expenditures and became millionaires. Now these powers demand the deposition of Ismail from the sultanate 9.10

In the same paper another article, abundantly illustrated, described Cairo and called it "the most beautiful city in the world". Its population was 450 thousand. There were Europeans among them, mainly Greek Christians. "However, what really has made Cairo world-famous are its scientific institutions, the khalifa's tombs and the Bulaq Press. 11

In 1880 and 1881 there was little news about Egypt. In these years the newspapers reported on the French in Tunisia. In connection with that the articles also mentioned Egypt.

Africa is becoming more and more a part of European politics. Hardly a year passes without a war in Africa. Europe wants to annex Mediterranean Africa. England wants to occupy Egypt, France has annexed Algeria and now wants to establish a protectorate in Tunisia. 12

Urabi's revolt is attention-worthy because European investments had been threatened in the otherwise stable Egypt, while radical and nationalist thoughts also posed a serious threat to the integrity of the Ottoman Empire. The Austro-Hungarian foreign policy related to the Egyptian Crisis such that, although it did not have strategic interests in the region, it tried to actively take its share and sought to achieve two goals. First, the monarchy was interested in acting in defense of Egyptian economic positions and Austrian-Hungarian citizens living in the Nile Country. The second principal interest was to prevent French-English cooperation, which threatened France becoming the most powerful nation in the world at that time. 13 
In 1882, however, a lot of articles were published about Egypt in Vasárnapi Ujjág (Sunday News). The articles were illustrated with pictures that showed the events and their protagonists. In the 8th issue of the paper (in February) an article entitled The Egyptian Question announced that the national party wanted to end foreign influence and the monetary control of the country:

... the movement aims to make Egypt belong to the Egyptians. For that reason, the Egyptian movement is on the one hand against the Ottoman sultan's control, whose authority was undermined in the latest war. To shake off Constantinople's yoke is just one of the aims. The main purpose is to get rid of the tyranny of Europe, and especially the English-French guardianship. 14

The article describes the events and also why the soldiers revolted and why they forced Khedive Tewfik15 to appoint ministers and leave the capital. The revolution broke out because "the French and English capitalists had sucked the country's blood." The leader of the national revolutionary movement "Urabi Pasha is extraordinarily talented, a great patriot and a courageous man, who can become the regenerator of his country". 16

The illustrated weekly paper devoted an article to Urabi Pasha in June. 17 "He is the leader of the Egyptian revolutionary movement, he has had control over it for years. He is in a difficult situation, because he is in opposition to the sultan and to Europe as well", but "he is considered worth of the task of a khalifa". He embodied the aims of the Egyptian people: to get rid of the Europeans, more precisely, "of the French and English creditors, who have collected twice the amount of the interests already." "Everybody is looking forward the outbreak of the revolution in Egypt, which will be the first one in the Islamic world."

In July the paper reported several times about the events in Alexandria, namely the bloody clashes between Europeans and Arabs. It described the coastal city as the city of European light and civilization. The first confrontation took place in this beautiful city on June 11.18 The next issue published the account of an Englishman about the events of June 11 entitled Bloodshed in Alexandria. The bloody clashes were provoked by a fight between an Arab and a Maltese man. According to his estimates 30 thousand Europeans fled the city. In the July 9 issue one could also read that Urabi Pasha tried to appease the Europeans, but he was not successful. The English ships continued the evacuation of Europeans. 19

The articles in August, September, and October reported about the military activities. Before the outbreak of the hostilities, the weekly described Urabi Pasha once more. A picture was also attached to the article depicting the head of the 
National party on horseback, riding in front of his soldiers. The article was full of praise: 20

Whatever opinion we should have about him, negative or positive, we have to admit that he is not an ordinary adventurer. He is a believer, he helps the poor, he himself rose from common ranks, and he has a coherent policy. His fellow countrymen respect him. He is loyal to the khedive, does not tolerate despotic government, and demands constitutional order. He promulgates complete equality for Muslims, Christians (the Copts), and Jews. Urabi is not an adventurer, but a patriot. We can already call him a historical figure.21

In the same paper there was an article and a photo about the bombardment of Alexandria. It remarked that the English cannons caused massive destruction in the city. They not only shot at military targets, but also at civilians, many of whom lost their lives. The newspaper returned to the issue of the bombardment of Alexandria in its subsequent issues, and expressed its hopes that the city would rise again from its ruins. 22

In September, several issues reported on the war itself. They introduced the military staff. There was a news item about Garnet Wolseley23 detailing where he had fought before (India, Crimean War). It also noted that he gave the command for the bombardment of Alexandria.24

The article entitled The Twenty-five Day War25 briefly summarized the most important events of the war from the English occupation of the Suez Canal to their entry to Cairo. The khedive returned to the city on September 25:

His entry was pompous even though it took place between the English bayonets. There is peace among the believers and the infidels right now, although, alas, only under the protection of the bayonets. 26

The last piece of news in the weekly paper reported about the trial and conviction of Urabi Pasha. A picture showed Urabi and his defence lawyer. The verdict was "guilty' and the sentence was death, which the khedive changed for lifelong exile. "The trial was simply a formality, it did not last five minutes." 27 


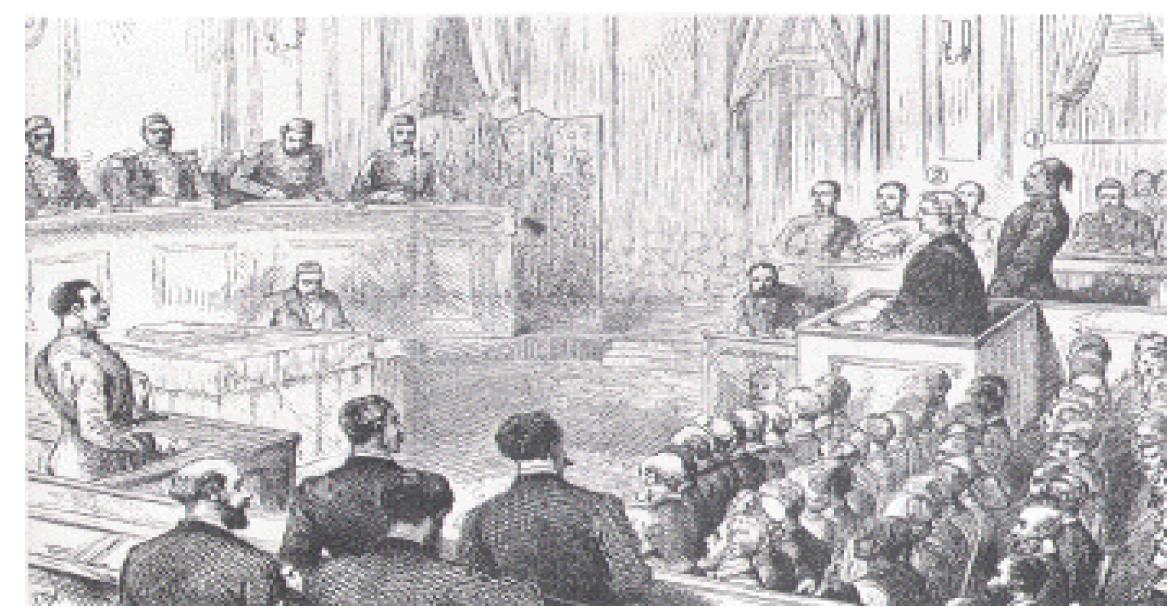

The trial of Urabi Pasha

Urabi Pasha lived in exile for 19 years in Ceylon (Sri Lanka), then returned to Cairo, where he died in 1911.28

Ignác Goldziher (1850-1921), the renowned researcher of Islam, one of the founders of scientific orientalism who knew much about Egypt (he visited the country many times and even studied at Al-Azhar), called the followers of Urabi Pasha a national party. This group opposed Ismail Khedive's regime. Those reformers belonged to this party who had European education and held European values important, and did not oppose the support of Europeans, but "oppose the absorption of the country by Europeans, which was also instigated by Ismail viceroy".29 That is, they would like Egypt to be modernized by Egyptians, and they did not want the Europeans (the English or the French) to dictate. In the national party's program of parliamentary government and the establishment of free institutions had an important role.

We can say that Ignác Goldziher defined the essence of Urabi Pasha's movement correctly: "Egypt belongs to the Egyptians, it is their task and not that of the foreigners to govern the country."

We can say the same about the weekly, Vasárnapi Ujjság, which provided accurate information for the Hungarian public about the events in Egypt and emphasized its national character. No wonder, as in those days Hungary was not completely independent either. It belonged to the Austro-Hungarian Monarchy, it was one of its determining components with broad autonomy, but it was not a sovereign country. And in those years the quest for independence became stronger and stronger. So, Vasárnapi Újság and a considerable part of the Hungarian public sympathised with Urabi Pasha's movement. 
While the weekly paper discussed the political events, it also reported on Egypt, and published articles about farming, about the ancient history of the country, and about the sights of Cairo and Alexandria. It introduced Egypt to the Hungarian readers.

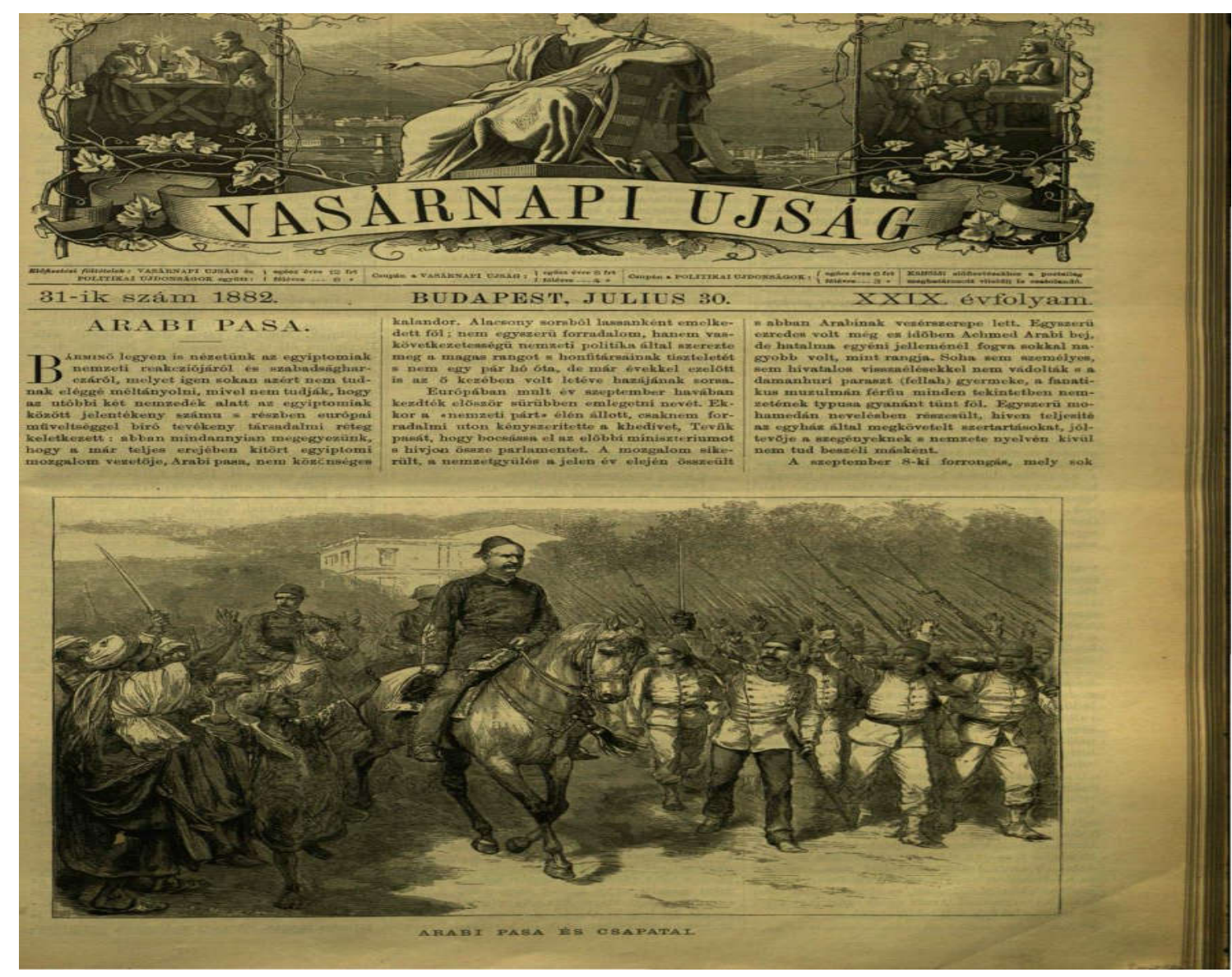

Urabi Pasa with his troops, Vasárnapi Újság, July 30, 1882. 


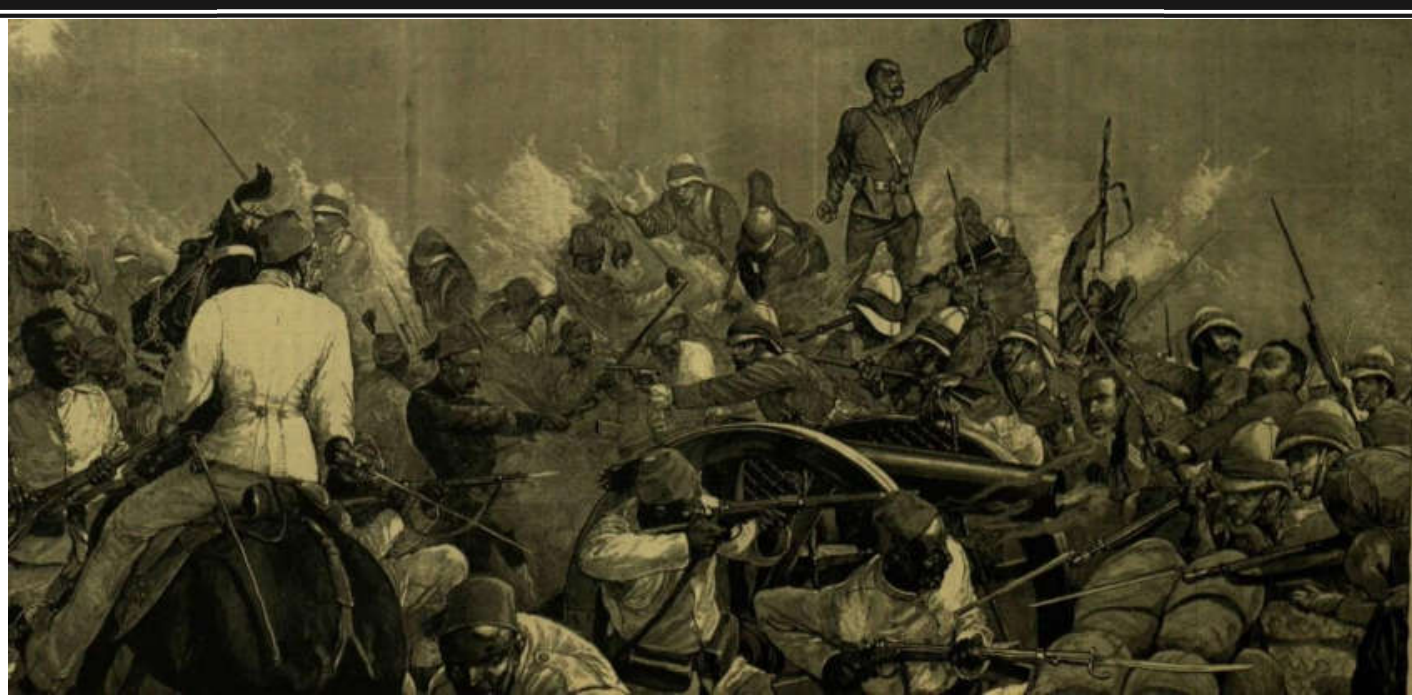

The Battle of Tel el-Kebir: 30 The Decisive Moment, September 13, 1882, Vasárnapi Újság 


\section{Footnotes}

1 Urabi or Orabi Pasha. Ahmed Mohamed Urabi Mohamed Wafi Gounem Abdullah Al-Husseiny (1841-1911) was an Egyptian nationalist, revolutionary and an officer of the Egyptian army. Urabi participated in an 1879 mutiny that developed into a general revolt against the Anglo-French dominated administration. He was promoted to Tewfik's cabinet, but the demonstrations in Alexandria of 1882 prompted a British bombardment and invasion that deposed Urabi and his allies in favour of British occupation. Urabi was tried by the restored Khedivate for rebellion, and pleaded guilty and was sentenced to death, but the sentence was immediately commuted to one of banishment for life. He left Egypt in December 1882, and returned to Egypt in 1901. (AbdelMoneim Ibrahim al-Gomeay, Muzakkerat al-Zaim Ahmed Urabi. Cairo, 2005, Dar el-Kotob 'The Egyptian National Library and Archives', 13-17.)

2 The first political and military Egyptian leader to rise from the fellahin, an Arabic word which means a farmer or agricultural labourer. The fellahin of Egypt have been described as the "true Egyptians".

3 One of the oldest Hungarian political newspapers (1850-1939).

4 Independent political daily newspaper (1878-1944).

$5 \mathrm{He}$ is known as Ismail the Magnificent (1830-1895). He was the Khedive of Egypt and Sudan from 1863 to 1879 . He greatly modernized Egypt and Sudan during his reign. In 1867 he also secured Ottoman and international recognition for his title of Khedive in preference to Wâli (Governor) which was used by his predecessors. However, Ismail's policies placed the Ottoman Khedivate of Egypt and Sudan (1867-1914) in severe debt, leading to the sale of the country's shares in the Suez Canal Company to the United Kingdom, and his ultimate toppling from power at British hands. (Ilias al-Ayouby Tarikh Misr fi Ahd al-Khedive Ismail Pasha. Cairo, 2013, Hindawi Foundation for Education and Culture, 40-84, and 805-832).

6 II. Abdul-Hamid sent a delegation to Cairo to mediate between the army and Khedive Tewfik. The delegation received a promising reply from both sides. Tewfik assured Porta of the loyalty of the new government. The goal was to avoid military intervention by European powers which was common. (Schölch: i. m. 156-160. In: Komár Krisztián, Az Osztrák- Magyar Monarchia és Egyiptom kapcsolatai 1882-1914, doktori értekezés, Szeged, 2012, Új Széchenyi Terv, 20-22).

7 Pesti Hírlap, June 27, 1879.

8 Muhammad Ali Pasha (1769-1849) was an Ottoman Albanian commander who rose to the rank of Pasha, and became Wāli of Egypt and Sudan. Though not a modern nationalist, he is regarded as the founder of modern Egypt because of the dramatic reforms in the military, economic and cultural spheres that he instituted.

9 Abdul Hamid II (1842-1918) was the Sultan of the Ottoman Empire (1876-1909).

10 Vasárnapi Újság, June 29, 1879.

11 The Bulaq or El-Amiriya Press is the first official governmental printing press to be established in Egypt, in 1820 by Muhammed Aly, and it as a part of his inclusive development plans for the modernization of Egypt.

12 Pesti Hírlap, April 15, 1881. Tunisia became a French Protectorate in 1882.

13 Komár Krisztián, Az Osztrák- Magyar Monarchia és Egyiptom kapcsolatai 1882-1914, doktori értekezés, Szeged, 2012, Új Széchenyi Terv, 18-29.

14 Vasárnapi Újság, February 19, 1882.

15 Mohamed Tewfik (1852-1892), was Khedive of Egypt and Sudan between 1879 and 1892 and the $6^{\text {th }}$ ruler from the Muhammad Ali Pasha Dynasty.

16 Ibid.

17 Vasárnapi Újság, June 12, 1882.

18 Vasárnapi Újság, July 2, 1882.

19 Vasárnapi Újság, July 9, 1882.

العقت الرابي أبريل (ما•مه) 
20 It was very exciting that the Hungarian newspapers had strongly praised and highly favoured Urabi Pasha. Meanwhile, most Egyptian daily and weekly papers attacked him and often referred to him as The Rebel instead of mentioning his name. See al-Ahram's Arabic editions from September 1, 1882 to December 20,1882. On the front page of al-Ahrampublished on September 1, 1882 it was reported that the English army had captured 650 rebels near Ismailia, and some officers from The Rebel Urabi's army surrendered themselves to the British forces in Salihia, saying that they were waiting with ,great patience and love for the British Army, and they have expressed their loyalty to Khedive Fennicity.” "The (English) warrior army is heading for Tel elKebir, where he receives all kinds of support from the Egyptian Mayor. The operation of the mechanized and well-equipped (English) army will be successful against the garrisoned rebels." Two days later, the same newspaper wrote that, under the command of Wolseley Marshal, a military unit led by Arthur, the son of the Queen of England, had actively and strongly attacked some of the troops of The Rebel Urabi army. "The Egyptian rebels, who fought hopelessly, suffered a severe and humiliating defeat at the al-Maskhota battle."

21 Vasárnapi Újság, July 30, 1882.

22 Vasárnapi Újság, August 7, 20, 1882.

23 Field Marshal Garnet Joseph Wolseley, 1st Viscount Wolseley (1833-1913) was a British army officer. He served in Burma, the Crimean War, the Indian Mutiny, China, Canada, and Sudan.

24 Vasárnapi Újság, September 17, 1882.

25 Vasárnapi Ujjág, September 24, 1882.

26 Vasárnapi Ujság, October 22, 1882.

27 Vasárnapi Ujság, December 31, 1882.

28 The Urabi movement had failed because Tewfik Khedive had betrayed him and supported the British interventions using all manner of means. Ferdinand de Lesseps also betrayed Urabi because he promised him the neutrality of the Suez Canal: he would not pass the British through the Canal, but exactly the opposite occurred. The Bedouins and some military officers also betrayed Urabi when they informed the British of all the activities of the Egyptian army. The Ottoman sultan declared Urabi as a rebel, which led many to withdraw from the Urabi front. We must take into account the modern and advanced British weapons and the use of the element of surprise of the attacker (Mahmoud al-Khefif. Urabi al-Zaim al-Muftara Alaih. Cairo, 2012, Hindawi Foundation for Education and Culture, 357-399.)

29 Ignác Goldziher: On Muslim Public Opinion. Budapesti Szemle (Budapest Review), 1882. Issue LXV, pp. 234-265.

30 It is about $110 \mathrm{~km}$ north-north-east of Cairo and 75 kilometres south of Port Said. It is a part of the Ismailia Governorate. 